\title{
Design of hazardous waste station in XYZ Port, Jakarta City
}

\author{
Andhika Yoga Wibisono, Disfiatri Kusumaningtyas, Salman Farid Lahmadi, \\ Alfiyah Najwa, Hafiz Arie Rachmantoro, Ariyanti Sarwono, I Wayan Koko \\ Suryawan* \\ Department of Environmental Engineering, Faculty of Infrastructure Planning, \\ Universitas Pertamina, Jakarta, 12220, Indonesia \\ i.suryawan@universitaspertamina.ac.id
}

Received 29-08-2020; accepted 24-09-2020

\begin{abstract}
The design of hazardous waste station is intended to adjust the security in the XYZ port area based on the fire and leakage possibility of hazardous waste generation. The research method used primary and secondary data to determine the availability of land area, and solid waste generation including its characteristics, respectively. The design of hazardous waste station was initiated with field observations to measure the land availability, and followed by secondary data collection to identify the volume, characteristics, and dimensions of hazardous waste collection. The composition of hazardous wastes, based on the solid waste characteristics, was flammable (20\%), flammable and toxic (56\%), toxic (23\%), and corrosive (1\%). The result suggested that the recommended dimension of the hazardous waste station was $11 \mathrm{~m} \times 8 \mathrm{~m}$. The container dimensions for leakage prevention were $2 \mathrm{~m} \times 2 \mathrm{~m} \times 0.6 \mathrm{~m}$ with a freeboard of $0.3 \mathrm{~m}$. The fire extinguisher was within a range of $12 \mathrm{~m}$.
\end{abstract}

Keywords: Hazardous Waste Station, Design, Port Area

\section{Introduction}

Port is the main gateway for a country to carry out economic activities. Port is not only meant for passenger services but is also meant for a traffic lane of goods' export-import. Indonesia ranks sixth after Hong Kong, Singapore, the Republic of Korea, Malaysia, and the United Emirates Arab in terms of container port's traffic levels [1]. The increasing market demand will also increase operational activities in the XYZ port area of Jakarta. Heavy equipment in the terminal is routinely used, which results in regular maintenance. Maintenance activities of heavy equipment produce hazardous and toxic waste in the form of oil, cables, and other hazardous goods that piled together. Liquid materials such as used oil are very likely to leak and be scattered, creating the risk of fire.

According to the International Labour Organization (I.L.O), the fire requirements can occur and enlarge due to several fuels or flammable substances, the existence of a lighters source, and the amount of oxygen in the air to support combustion [2]. From the three fire conditions, flammable material is always in the hazardous waste station, while oxygen is always in free air, only a lighter which has not

Cite this as: Wibisono, A.Y., Kusumaningtyas, D., Lahmadi, S.F., Najwa, A., Rachmantoro, H.A., Sarwono, A \& Suryawan, I.W.K. (2020). Design of hazardous waste station in XYZ Port, Jakarta City. Civil and Environmental Science Journal (Civense), 3(2), 110-118. doi: https://doi.org/10.21776/ub.civense.2020.00302.6 
met the occurrence of a fire, but the existence of a lighter source in the hazardous waste station area is very possible, among others: short circuit possibility from an electrical device, many vehicles passed by allowing road users to dispose cigarette butts [3]. If hazardous waste is not managed properly, it will impact on all living things and natural environments on this earth [4]. Details are regulated by the law starting from the source of waste, storage, transportation, and destruction. Hazardous waste management is important, if intentionally mixing hazardous waste without knowing their individual characteristics, unforeseen events will potentially occur, such as sudden burning and exploding. There are several aspects of burning such as fire extinguishers, direct sunlight, and hazardous waste mixing that is not based on its characteristics but it is recommended for one concept to only be filled with 1 type of hazardous waste. Based on the Government Regulation No.101 of 2014 [5], the area of waste station must accommodate hazardous waste generated routinely (/day, /week, /month, etc.). Each hazardous waste package must be symbolized and labeled, to identify if there is hazardous waste in the area otherwise it will endanger workers when they misuse the hazardous waste.

For container design, the volume of the container is designed by multiplying the volume of each hazardous liquid waste by $110 \%$. Based on SNI 03-6572-2001 regulations for ventilation design of storage/warehouse (category seven [6], it requires ventilation with an area of at least $10 \%$ of the floor area and ventilation height of no more than 3.6meters from the floor. The arrangement of fire extinguishers, based on NFPA 13 of 2013 [7], the placement of fire extinguishers must be arranged with the height of the top (head) of the fire extinguisher about 1.2 meters from the floor surface. The location of fire extinguishers is also regulated based on NFPA 10 of 2013 [7]. The location of fire extinguishers is as far as 23 meters from a potentially flammable sources and metal source of fire extinguishers is needed if the characteristics of the hazardous waste produced are flammable, thus, when a minor fire occurs, it can be immediately overcome because the provision of fire extinguishers is readily accessible and the placement of fire extinguishers is located properly [8]. In making symbols and labels, it must be installed on the package (drums) of hazardous waste as a sign of hazardous waste and it must label their respective characteristics. The symbol size used is $15 \times 15 \mathrm{~cm}$, whereas the label size used is 25 x $40 \mathrm{~cm}$ according to KEP05 / BAPEDAL/09/1995 [9].

Providing a waste transfer station, in accordance with the regulations of the Minister of Environment and Forestry No. P.12 2020 [10] concerning the storage of hazardous and toxic waste materials, can prevent the risk of environmental impacts, especially from fires. In addition, the company will achieve a good rating from an auditor. The purpose of this work is to design a hazardous waste station to be safe from the risk of fire by taking the composition of the waste.

\section{Material and Methods}

\subsection{Field Observation}

Field observations were conducted to examine the capacity of the land. Measurements were carried out in areas that are safe from disturbance and have no potential of causing environmental impacts.

\subsection{Generation and Composition}

Hazardous waste generation data was obtained from the logbook inventory at XYZ port for three months. The composition of hazardous waste was differentiated based on its characteristics, which are flammable and corrosive. The generation and composition data were obtained from secondary data.

\subsection{Design}

Solid waste volume is calculated based on solid waste generation and multiplied by a safety factor of $30 \%$. The frame of the waste bin often experiences fluctuating loads from hazardous waste loads therefore, dynamic loads was anticipated [11]. The equation used is in accordance with equation 1.

Volume of waste $=$ waste generation $\times 30 \%$ 
From field observation, the estimation volume of waste spills can be calculated based on Equation 2. The placement between fire extinguishers is adjusted to Permenaker No. 04/ MEN/1980 [12]. The range of fire extinguishers is designed 15 meters from the placement.

Volume wastewater $=$ volume solid waste $\mathrm{x} \sum$ drum

\section{Result and Discussion}

\subsection{Hazardous Waste Generation and Composition}

Based on the secondary data on the volume of hazardous waste generated, the data obtained from the generation of waste each month are subsequently accumulated for 3 months. Inventory data was used to measure the generation and composition of hazardous waste usually use [13, 14]

The generation and composition of hazardous waste for 3 months in port area are presented in Table 1. Based on the packaging volume, textile waste, used oil and grease are put in a $200 \mathrm{~L}$ drum; the filter is put in a $120 \mathrm{~cm} \times 120 \mathrm{~cm}$ wooden box; and the wire and used battery are directly laid on the pallet because the wire is already in the form of rolls and the used battery already has its container. Used cloth/textiles have flammable characteristics, because this waste contaminated with oil, grease or gasoline. This is similar to Fajriyah and Wardhani which state that fuel contamination of the textiles cause the textile to become flammable [15]. Oil cleaning activities on machines can cause high use of textiles, especially ship engines at ports. Toxic waste can be treated with an incinerator and must pay attention to disposal of the ash generation by stabilization [16].

Table 1. Generation and Characteristics of Hazardous Waste in Port Area

\begin{tabular}{lllllll}
\hline No & Type of Waste & Characteristics & $\begin{array}{l}\text { Amount per } \\
\text { month }\end{array}$ & $\begin{array}{l}\text { Amount of } \\
3 \text { month }\end{array}$ & $\begin{array}{l}\text { Density } \\
\left(\mathrm{kg} / \mathrm{m}^{3}\right)\end{array}$ & $\begin{array}{l}\text { Volume } \\
\left(\mathrm{m}^{3}\right)\end{array}$ \\
\hline 1 & Used cloth/textile & Flammable & $280 \mathrm{~kg}$ & $840 \mathrm{~kg}$ & 180.66 & 4.65 \\
\hline 2 & Used oil & $\begin{array}{l}\text { Toxic and } \\
\text { Highly } \\
\text { Flammable }\end{array}$ & $800 \mathrm{~kg}$ & $2400 \mathrm{~kg}$ & 800 & 3 \\
\hline 3 & Grease & $\begin{array}{l}\text { Toxic and } \\
\text { Flammable }\end{array}$ & $2 \mathrm{~kg}$ & $6 \mathrm{~kg}$ & 953 & \multirow{2}{*}{0.0063} \\
\hline 4 & Oil filter & Toxic & $200 \mathrm{pcs}$ & $600 \mathrm{pcs}$ & & \\
\hline 5 & Wire & Toxic & 2 rolls & $6 \mathrm{rolls}$ & & \\
\hline 6 & Used battery & Corrosive & $7 \mathrm{pcs}$ & $21 \mathrm{pcs}$ & & \\
\hline
\end{tabular}

The composition of hazardous waste $(\mathrm{w} / \mathrm{w})$ can be seen in Figure 1. This composition is used in determining storage and storage place at the waste station. The volume of storage used is $0.18 \mathrm{~m}^{3}$ with a capacity of 209 litters. The maximum volume and capacity of hazardous waste packaging can be utilized to determine the number of packages to be used.

Storage used is divided into two types namely drums and wooden boxes. Other research also mentions used oil or flammable waste packaged in drums [17, 18]. This waste, nearby fire/sources of fire, sparks, and easily list friction in a long time either during transportation, storage, or disposal, thus the container must be kept safe from it. 


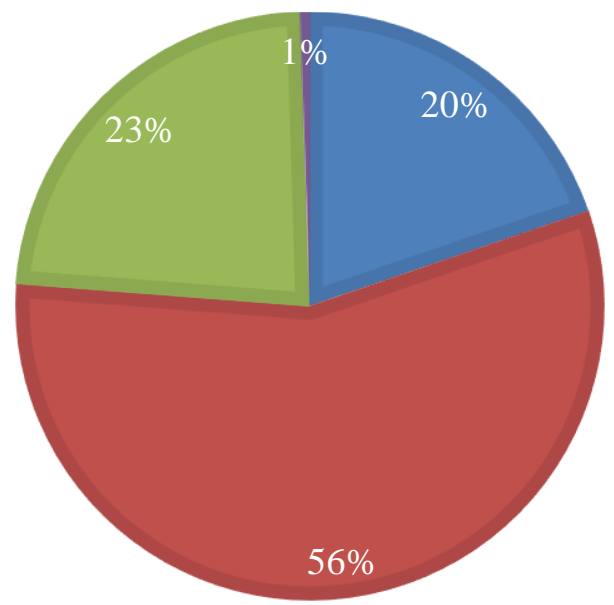

Figure 1. The composition of hazardous waste in the study area.

Based on field observations, the land area that can be used as a waste station is $11 \mathrm{~m} \times 8 \mathrm{~m}$. Waste management must consider the characteristics of waste, in which different waste characteristics must be spaced at least $60 \mathrm{~cm}$ and combustible waste must be given a wall with a thickness of $15 \mathrm{~cm}$, made of concrete and $23 \mathrm{~cm}$, made of bricks. The previous design mentioned that hazardous waste generation of $12 \mathrm{~kg} /$ week requires a land area of $4 \mathrm{~m} \times 3 \mathrm{~m}$ [19].

Toxic and corrosive waste is stored in containers with provisions. For storage in the form of tanks and/or containers, the requirements are: the packaging material must be able to store hazardous waste; and the packaging must have a strong cover to avoid spillage during storage, transfer and/or transportation; the packaging must also be in good condition, rustles, intact, and no leakage.

Some requirements must be fulfilled [20] such as; the container of materials must be in accordance with the character of hazardous waste; all containers must be stored in a closed area protected from rain and ventilated; and the ground floor of the building must be waterproof to avoid absorbing spills or spills leak. The number of drums and wooden boxes needed can be seen in Table 2. Dimension of drums and wooden boxes can see in Figure 2.

Table 2. The number of drums and wooden boxes needed in hazardous waste transfer station

\begin{tabular}{|c|c|c|c|c|c|}
\hline No & Type of Waste & $\begin{array}{l}\text { Number of } \\
\text { drums }\end{array}$ & $\begin{array}{l}\text { Volume } \\
\text { of drums }\end{array}$ & $\begin{array}{l}\text { Number } \\
\text { of } \\
\text { Containers }\end{array}$ & $\begin{array}{l}\text { Dimension } \\
\text { of wooden } \\
\text { boxes }\end{array}$ \\
\hline 1 & $\begin{array}{l}\text { Used } \\
\text { cloth/textile }\end{array}$ & \multirow{3}{*}{43} & \multirow{3}{*}{$200 \mathrm{~L}$} & & \\
\hline 2 & Used oil & & & & \\
\hline 3 & Grease & & & & \\
\hline 4 & Filter & & & 2 & $120 \mathrm{~cm} \mathrm{x}$ \\
\hline 5 & Wire & & & 3 & $120 \mathrm{~cm}$ \\
\hline 6 & Used battery & & & 1 & \\
\hline
\end{tabular}



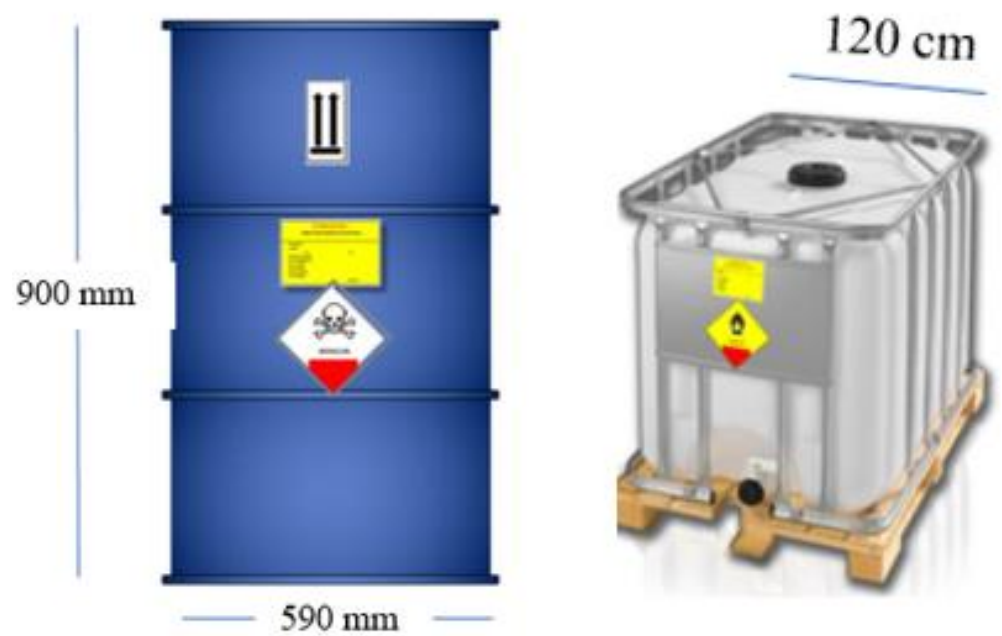

Figure 2. Dimension of Drums and Wooden Boxes Based on Guidelines for Issuance of Recommendations for the Transportation of Hazardous and Toxic Waste [21]

The symbols and labels used must be in line with the characteristics of the waste produced and refer to PERMENLH No. 14 of 2013 concerning hazardous waste symbols and labels [22]. Symbols are placed on both filled and empty packaging to facilitate the placement and the use of the container. The symbol on the container is $15 \mathrm{~cm} \mathrm{x} 15 \mathrm{~cm}$ (Figure 3) and is in accordance with the waste characteristics. The following are the symbols used on Hazardous Waste Station.
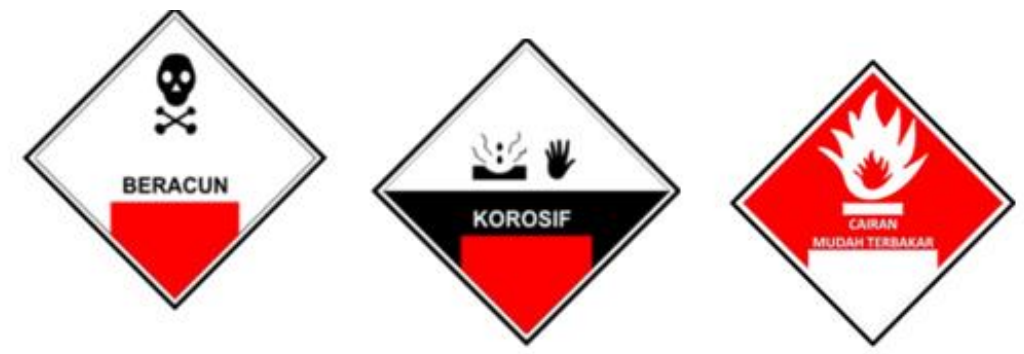

Figure 3. Symbols of Hazardous Waste for Hazardous Waste Station [22]

The Hazardous Label contains complete information on the classification and types of hazardous waste along with a brief description in order to facilitate the handling of waste and to avoid accidents to workers. The Hazardous Label must be proportional and readable. The size used on Hazardous Label is $35 \mathrm{~cm} \mathrm{x} 25 \mathrm{~cm}$.

All drums are stored in racks based on hazardous waste characteristics. Used cloth / textile, grease, and oil are stored in one shelf because they use drums and are specifically for combustible materials. Meanwhile, wooden boxes that provide other waste such as filters, wires, and used batteries are placed in one rack. Shelf placement is adjusted according to the regulation as in Figure 4. 


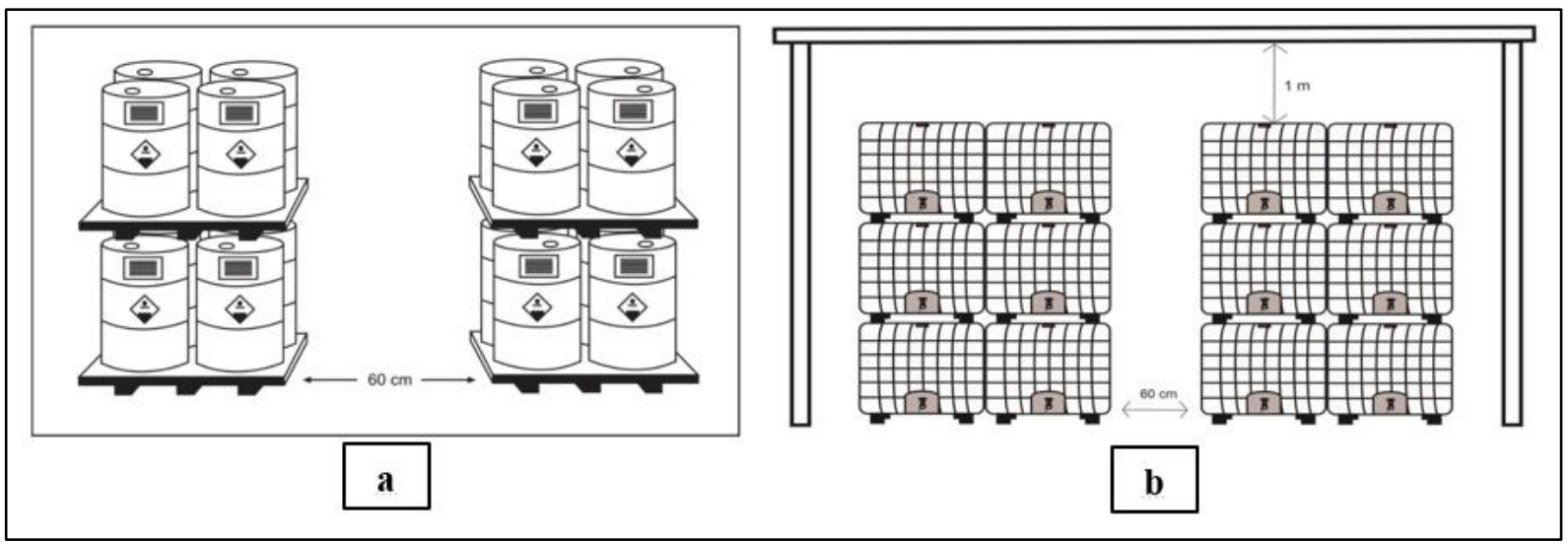

Figure 4. Rack placement on Hazardous Waste Station (a) for Drum and (b) for Wooden Boxes [21]

\subsection{The Design of Hazardous Waste Station Leakage Prevention}

The container is used to collect spills in the hazardous waste station. It is an important facility because waste spills are prohibited from being directly disposed of in the drainage system. This calculation is based on the waste volume, and the waste spill volume. The waste volume per drum is by assumption of $30 \%$ of the waste generation shown in equation 1 . If the number of drums in the industry is 43 , the total volume of waste spills can be calculated (equation 2).

$$
\begin{aligned}
& \text { Volume }_{\text {waste }}=0.18 \times 30 \%=0.054 \mathrm{~m}^{3} \\
& \text { Volume }_{\text {waste spills }}=0.054 \mathrm{~m}^{3} \times 43=2.322 \mathrm{~m}^{3}
\end{aligned}
$$

From the above calculation, Total Spill Volume is $2,322 \mathrm{~m}^{3}$, obtained from the dimensions of the storage area with a value of $2 \mathrm{~m} \times 2 \mathrm{~m} \times 0.6 \mathrm{~m}$ and a $0.3 \mathrm{~m}$ freeboard. The data are considered sufficient for the manufacture of hazardous waste container for storage. The volume of storage containers, for individual hazardous liquid waste, is designed by multiplying the volume of hazardous liquid waste by $110 \%$, in accordance with Head of Bapedal No. 01 of 1995 [23]. Leaked collection tank is also added with soil with permeability of $10^{-5} \mathrm{~cm} / \mathrm{second}$ in accordance with applicable regulations [21].

Based on the Decree of the Head of Bapedal No. 01 of 1995 [23], concerning Procedures and Technical Requirements for the Hazardous and Toxic Waste Storage and Collection, the floor at Hazardous Waste Station must have a maximum slope of $1 \%$ to drain leaks so that leaks can flow directly into the trench and be collected in the reservoir. The plan picture for a wastewater collection is depicted in Figure 5.

To prevent the release of hazardous waste into the environment, tanks and / or containers are equipped with secondary storage [10]. Secondary storage can take the form of one or more of the following conditions [10]:

1. Is made or coated with a material which is compatible with the hazardous waste being stored and has sufficient thickness and strength to prevent damage due to pressure effects;

2. Is placed on a foundation or base that can support resistance tank and/or container against pressure from above and below and is able to prevent damage caused by filling, pressure or uplift;

3. Equipped with a leak detection system designed and operated for 24 (twenty four) hours so that it is capable of detecting damage to the tank structure and/or primary and secondary containers, or the release of hazardous waste from the secondary storage system; and

4. Secondary storage, designed to accommodate and lift liquids from leaks, spills or precipitation. 


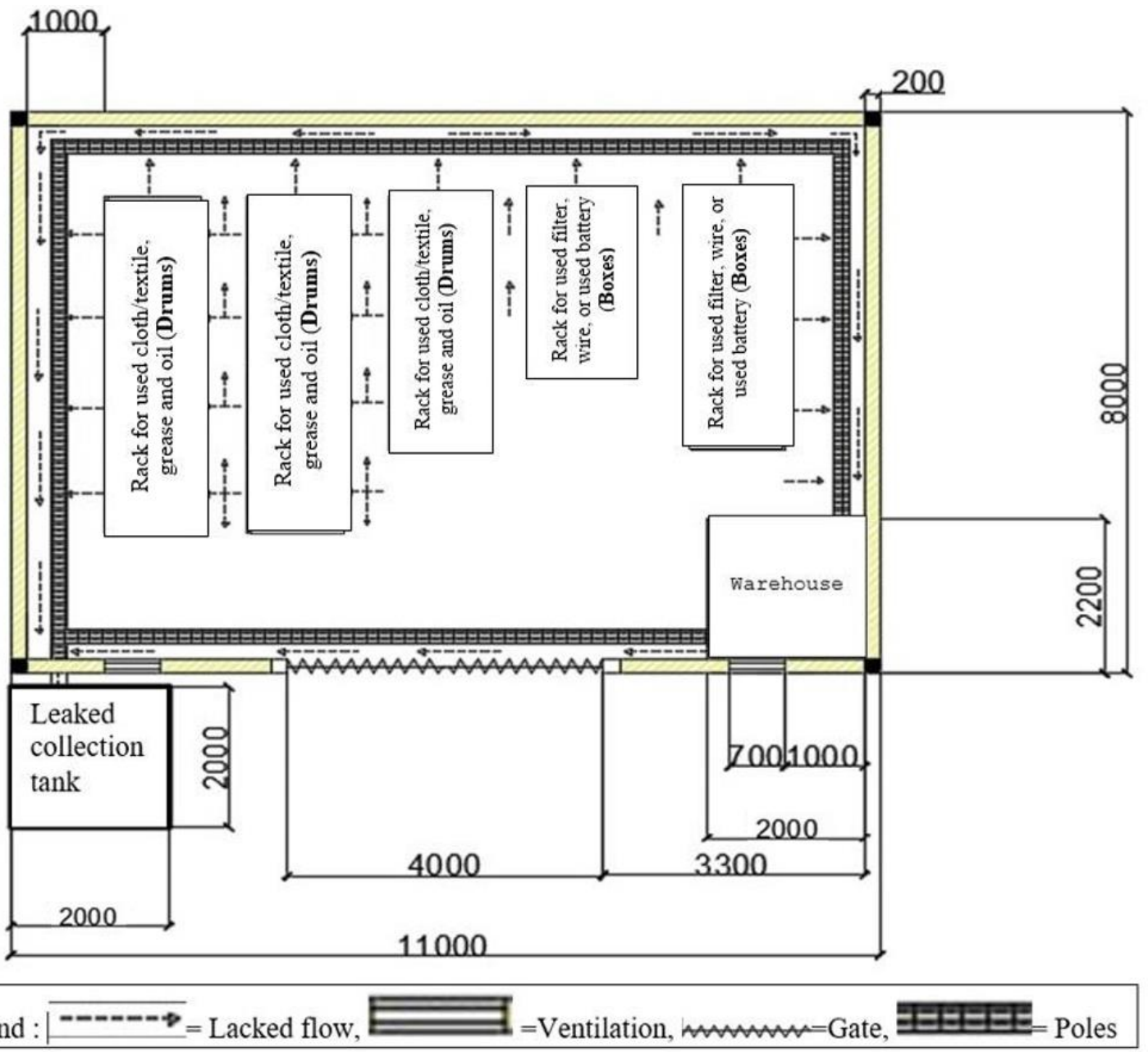

Figure 5. Top View of Hazardous Waste Station in XYZ Port Area

\subsection{The Design of Hazardous Waste Station Fire Prevention}

The characteristics of hazardous waste to be stored is of great importance especially in building materials selection. This is to prevent accidents such as fires caused by combustible waste. The materials selection, which can be used as storage walls, can utilize red brick walls with a minimum thickness of $23 \mathrm{~cm}$. Likewise, roof construction may employ asbestos materials to resist corrosion and fire [24].

Based on Permenaker No. 04/ MEN/ 1980 [12], the installation of fire extinguishers must meet the requirements. Single or multiple fire extinguisher(s) must be placed in a position that is easily seen, readily reached, and taken, as well as accompanied by a sign of installation. The marking must agree with Permenaker No. 04/ MEN/ 1980 [12]. Each extinguisher must be placed with a maximum distance of 15 meters between them unless otherwise stipulated by a safety employee or work safety experts. Each fire extinguisher must be mounted to a wall by reinforcement or with other reinforcement construction or placed in an unlocked cabinet or box. The fire extinguishers installation must follow the above conditions; thus, the dry powder type of fire extinguishers can be placed lower so that the distance between the fire extinguishers base is not less than $15 \mathrm{~cm}$ from the floor surface. The fire extinguisher model may adopt Chemical Powder Multi-Purpose $9 \mathrm{~kg}$. The fire extinguisher was chosen because it has a wide spray range and is less heavy. The effective of $95 \%$ is obtained from product specifications, in this design plan it is known that the longest range of one fire extinguisher is $7.5 \mathrm{~m}$ where $95 \%$ effectiveness means that at a distance above $7.125 \mathrm{~m}$ fire extinguishing is less effective. 


\section{Conclusion}

With the largest flammable and toxic composition of 56\%, hazardous waste in the XYZ port area requires land of $11 \mathrm{~m} \times 8 \mathrm{~m}$. Based on the needs of the container, the size of the container is $2 \mathrm{~m} \times 2 \mathrm{~m}$ $\mathrm{x} 0.6 \mathrm{~m}$. While the effective rate of fire extinguishers is $95 \%$.

\section{References}

[1] D. W. Te Velde and United Nations Conferenceon Tradeand Development., "Foreign direct investment and development: An historical perspective," London: Overseas Development Institute ODI, 2006.

[2] I.L.O., Manajemen Risiko Kebakaran, Jakarta: International Labor Office, 2018.

[3] P. A. Nugroho, S. Prasetya, A. Rozaq and A. Iswanto, "Rancang Bangun Alat Pendeteksi Kebakaran Pada Tempat Penyimpanan Sementara Limbah B3," Seminar Nasional Teknik Mesin,, vol. 9, no. 1, 2019.

[4] S. Yudi, "Rawannya Pelanggaran Dalam Pengelolaan Limbah Bahan Berbahaya dan Beracun," Lingkar Widyaiswara, vol. 1, pp. 41-46, 2014.

[5] Indonesia Government, Government Regulation No. 101 of 2014 Regarding Hazardous Waste Management, Jakarta, 2014.

[6] BSN, "SNI 03-6572-2001 concerning procedures for designing ventilation and air conditioning systems in buildings," 2001.

[7] NFPA13, Standard for the Installation of Sprinkler Systems, USA: Quincy Massachusetts, 2013.

[8] Megawati and T. W. Panjaitan, "Perancangan Proses Penyimpanan Limbah Bahan Berbahaya dan Beracun di PT. ETA Indonesia. Titra." Jurnal Titra, vol. 3, no. 2, pp. 129-134, 2015.

[9] BAPEDAL, Head of Bapedal Decree No. 5. Kep-05 / BAPEDAL / 09/1995 concerning Procedures for Labeling and Symbols of Waste, 1995.

[10] Ministry of Environment and Forestry, Minister of Environment and Forestry No. P.12 2020 concerning the storage of hazardous and toxic waste, Jakarta: Kementrian Lingkungan Hidup dan Kehutaan, 2020.

[11] L. A. Wibawa, "Desain dan Analisis Kekuatan Rangka Tempat Sampah di Balai LAPAN Garut Menggunakan Metode Elemen Hingga.," TURBULEN Jurnal Teknik Mesin, vol. 1, no. 2, pp. 64-68, 2018.

[12] Minister of Manpower and Transmigration, Minister of Manpower and Transmigration Regulation No. Per 04 / Men / 1980 regarding the requirements for installation and maintenance of light fire extinguishers, 1980.

[13] S. D. Prameswari, M. A. Nurhadi, I. Rizaldi, M. Octaviani, I. W. K. Suryawan and B. Ridhosari, "Design of Hazardous Waste Station in Xyz Radioactive Industry.," ENVIROTEK: Jurnal Ilmiah Teknik Lingkungan, vol. 12, no. 1, pp. 80-86, 2020.

[14] I. Suryawan, Evaluasi Pengelolaan Limbah Padat B3 Di Fasilitas Incinerator Untuk Puskesmas Kota Surabaya, Surabaya: Institut Teknologi Sepuluh Nopember, 2014.

[15] S. A. Fajriyah and E. Wardhani, "Evaluasi Pengelolaan Limbah Bahan Berbahaya dan Beracun (B3) di PT. X.," Jurnal Serambi Engineering, vol. 5, no. 1, pp. 711-719, 2020.

[16] I. W. K. Suryawan, G. Prajati and A. S. Afifah, "Bottom and fly ash treatment of medical waste incinerator from community health centres with solidification/stabilization," AIP Conference Proceedings, vol. 2114, no. 1, p. 050023, 2019.

[17] A. E. Afiuddin and A. K. Dwi, "Studi Perbaikan Tempat Penyimpanan Sementara (TPS) Limbah B3 Sesuai Dengan Limbah Yang Dihasilkan Dan Peraturan Terbaru Di PT. X.," IPTEK Journal of Proceedings Series, vol. 2, pp. 78-84, 2018.

[18] R. W. Pratiwi, A. Setiawan and A. E. Afiuddin, "Perancangan Tempat Penyimpanan Sementara (TPS) Limbah B3 (Studi Kasus: Bengkel Maintenance PT. Varia Usaha)," Seminar K3, vol. 1, no. 1, pp. 199-204, 2017. 
[19] T. N. Pramestyawati, "Pengelolaan Limbah Bahan Berbahaya Dan Beracun (B3) Laboratorium Klinik Di Sumber Limbah," Prosiding Seminar Teknologi Perencanaan, Perancangan, Lingkungan dan Infrastruktur, vol. 1, no. 1, pp. 471-476, 2019.

[20] N. Anggarini, S. Megi and Prihatiningsih., "Pengelolaan dan Karakterisasi Limbah B3 di Pair Berdasarkan Potensi Bahaya," Beta Gamma, vol. 5, no. 1, pp. 41-49, 2014.

[21] Ministry of Enviroment, " Guidelines For Issuance Of Recommendations For The Transportation Of Hazardous And Toxic Waste," 2015. [Online]. Available: http://pelayananterpadu.menlhk.go.id/images/dokumen/nonperizinan/PEDOMANPENERBITAN-REKOMENDASI-PENGANGKUTAN-LIMBAH-BAHANBERBAHAYA-DAN-BERACUN-FINAL.pdf. [Accessed 2009 2020].

[22] Ministry of Environment, PERMENLH No. 14 of 2013 concerning Hazardous Waste Symbols and Labels, Jakarta: Ministry of Environment, 2013.

[23] BAPEDAL, Decree of the Head of Bapedal No Kep-01 / Bapedal / 09/1995 concerning Procedures and Technical Requirements for Storage and Collection of Hazardous and Toxic Waste,Jakarta, 1995.

[24] I. W. Murti and A. H. Ibrahim, "Identifikasi Bahaya dan Perancangan Tempat Penyimpanan Sementara (TPS) Limbah B3 Proses Sandblasting Di PT Swadaya Graha," ENERGY, vol. 8, no. 1, pp. 1-7, 2018. 